\title{
Empirical and numerical investigation on the thermal efficiency of a tripartite transparent covered hexagonal composite salt-gradient solar pond with East-West side reflector
}

Keywords:

Posted Date: April 13th, 2021

DOI: https://doi.org/10.21203/rs.3.rs-250017/v2

License: (c) (1) This work is licensed under a Creative Commons Attribution 4.0 International License. Read Full License 


\section{Abstract}

The authors have requested that this preprint be removed from Research Square. 